\title{
Gender Equality and Education for Sustainable Development- General Overview and Way Forward
}

\author{
Ajaz Ahmad Lone ${ }^{1}$, Inayat Ullah Dar ${ }^{2}$ \\ Research Scholar, Department of Education, DAVV University, Indore, M.P, India \\ Teacher, Department of School Education, Kashmir, India \\ Email:aijazabdullahlone@gmail.com
}

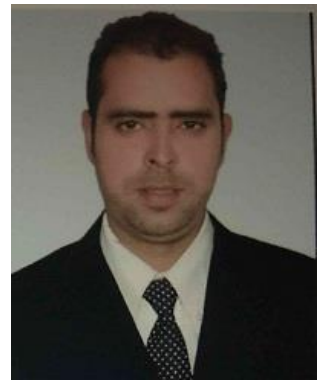

AJAZ AHMAD LONE

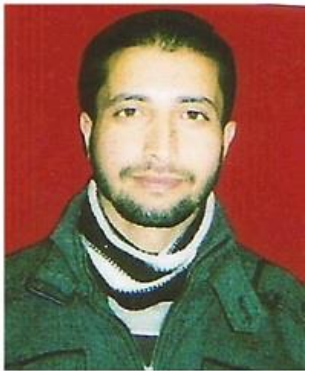

INAYAT ULLAH DAR

Keywords:

The Universal Declaration of Human Rights (UDHR), World Economic Forum (WEF), Self Help Groups (SFGs)

\begin{abstract}
A B S T R A C T
According to Medical Women's International Association's Training Manual for Gender Mainstreaming in Health (2002), "Gender equality refers to the equal rights, responsibilities and opportunities of women and men; and girls and boys." World Survey on The Role of Women In Development. "Gender Equality And Sustainable Development" by the United Nations (2014) says, Gender equality implies that the interests, needs and priorities of both the sexes are taken into consideration, recognizing their diversity and coming up with something very substantial in a better future. Gender equality is an approach towards human right principle and a basic prerequisite for sustainable, nation-centered development for improving the overall status of life and living standards. Integrating gender equality with sustainable development requires profound conceptual understanding of both concepts and their inter-linkages in actual settings. Gender Equality and Sustainable Development report of United Nations further asserts that, "any real advances in sustainable development cannot be achieved without commitment of gender equality and the inclusion of women."
\end{abstract}

Citation: Ajaz Ahmad Lone, Inayat Ullah Dar (2019). Gender Equality and Education for Sustainable Development- General Overview and Way Forward. International Journal of Advanced Multidisciplinary Scientific Research (IJAMSR) ISSN:2581-4281, 2 (1), January, 2019, \# Art.1118, pp 52-58 


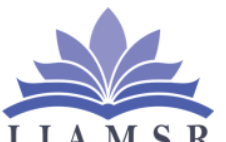

\section{International Journal of} Advanced Multidisciplinary Scientific Research (IJAMSR) ISSN:2581-4281

\section{Introduction}

The principle of gender equality men and the consequent prohibition of discrimination is a fundamental principle of international human rights law. The Universal Declaration of Human Rights (UDHR) adopted by the United Nations General Assembly in 1948 proclaims under its article 1 that, "All humans are born free and equal in dignity and rights irrespective of the gender; are gifted with reason and the power of thinking; and should act towards one another in a spirit of brotherhood to develop social harmony."

The paper is evaluative study and focuses to come up with some remedial and preventive measures/suggestions to ensure how Gender equality could be achieved within possible and limited resources by effective and optimum utilization; and sustainable development thereof.

Linking gender equality and education with sustainable development is important for several reasons as it puts weight behind the fact that we can't overcome the problems of sustainability unless and until every stakeholder is taken into account and considered and given proper weight-age thereof. Efforts to achieve a just and sustainable future cannot ignore the rights, dignity and capabilities of half the world's population, who are proving themselves at all levels globally. Sustainable development is subservient only when we would redress the lopsided impact on women and girls of financially workable, social and environmental shocks and stresses and it is a moral and ethical imperative for one and all. Finally, women's knowledge and wisdom, agency and collective action have massive potential to perk up resource productivity, enhance ecosystem conservation, sustainable use of natural resources and Human life index, and to create more sustainable, low-carbon food, energy, water and health systems for coming generations. Failure to capitalize on this would be a missed opportunity and a huge lapse on the part of present reformers, philosophers and intellectuals. Women should not be viewed as victims, but as central actors in moving towards sustainability and prosperity tomorrow and there is a dire need to shun this kind of stereotypical approach.

\section{Review of Literature:}

A thorough review of literature was done in order to get a comprehensive view of the earlier works and to gain proper understanding of the problem under research. Gender equality is considered to be a significant moral principle that should be followed by all members/sections of society as it pertains to ethics of human life. According to Louden (2013), the issue of gender quality requires promotion of moral principles in relation to women and male folk needs to be given due courses of counselling to understand the need of gender equality till stereotype is culminated. Gender equality is not just the concern of half of the world's population; it is a human right, a concern for us all, because no society can develop-economically, politically, or socially-when half of its population is marginalized. 


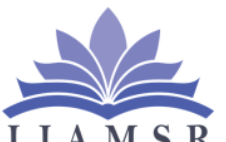

\section{International Journal of} Advanced Multidisciplinary Scientific Research (IJAMSR) ISSN:2581-4281

As per Bashar (2008), a famous saint, known as Sheikh Noor-ud-Din Noorani, commonly called as Nund Reshi of Kashmir said "Ann Poshe Tele Yele Wun Poshe" meaning "Food will last as long as Vegetation lasts". This clearly depicts the emphasis being given to the protection and conservation of natural resources and sustainable development. And religious clerics need to have a holistic view to inculcate the proper sense of belongings among their followers as we; Indians are mostly idealistic in our philosophies and hence becomes an imperative for all religious figures to channelize their followers to do something substantial and sustainable rather than triggering intolerance among mass vis-a-vis religion and teaching of the respective religions. Similarly, every religion has laid stress on the education of humans irrespective of sex and we need to overcome orthodoxy and extremism in order to move towards sustainable development.

All three terms, i.e. Education, Gender Equality and Sustainable Development are so interconnected that Education helps us to overcome the gender disparity or inequalities by its operation on the ground; and later pushes us towards sustainable development. In other words, we can say that Education is an agency to change our outlook regarding various domains of the life, Gender equality gives us the opportunity to work think on democratic lines to empower our women folk to utilize, channelize and nurture their innate capabilities and capacities for better and sustainable future.

\section{Definitions:}

Gender Equality: According to United Nations International Children's Emergency Fund (UNICEF), "Gender equality means that women and men, and girls and boys, enjoy the same rights, resources, opportunities and protections." It is $5^{\text {th }}$ of seventeenth sustainable development goals of the United Nations.

Sustainable Development: As far has the definition is concerned, there isn't any full and final definition of sustainable development due to being very diversified in its spectrum. However, as per Brundtland report, "Sustainable development is that special kind of development were under the needs of the present are met without compromising the ability of future generations to meet their own needs and demands."

\section{Importance:}

According to a report by ActionAid, economic inequality for women costs a staggering loss of around $\$ 9$ trillion per year in the developing world. If both sexes had equality in work, it would increase gross domestic product (GDP) in various countries including India by between $5 \%-34 \%$, says the International Monetary Fund. Countries with higher gender equality levels tend to have higher economic growths and moving positively towards sustainable development.

Gender equality is an outcome or product of the process or phenomena called as Education and education in itself can't be reach to the desired horizons unless and until former isn't achieved. So we can say both gender equality and education are two sides of the same coin 


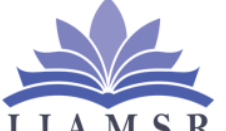

\section{International Journal of} Advanced Multidisciplinary Scientific Research (IJAMSR) ISSN:2581-4281

and the target of attaining sustainable development is far off dream in the absence of these two activities. The implications of not providing women folk with equal rights and opportunities affect not just their lives, but the future of this mother earth, we live on. Efforts to promote inclusive sustainable development and fight drastic and unfavorable climate changes are inextricably linked. So, it is crystal clear from these facts that sustainable development is something very distant to achieve in view of the present gender inequality in South Asia in general and in India in particular. The gender inequality in India is attributed to many reasons like religious orthodoxy, casteism or regionalism etc. All these factors have been pushing us to the wall since times immemorial and we, as a nation are yet to eradicate the same, which puts a big challenge in front of us at present in the future. The educational system as a whole is deemed to be very much responsible for not actually nurturing the national interests.

\section{Prevalence:}

As per the reports published by The Wire, India's growth performance in recent years suffers from a peculiar socioeconomic problem that defies the conventional wisdom addressing distributive benefits of higher economic growth. And further it is reported that the rate of aggregate growth over the last decade has considerably taken an upward trend across the country, relational inequalities surfacing from traditionally-established social hierarchies further proliferate many folds and have hindered the overall development of the country to a large extent. There are many factors responsible for this inequality i.e. Lack of realism and quality Access to Education for girls, healthcare, the ill attitude of employers towards women folk, and women harassment at work places, household violence and religious bigotry.

According to the WEF Global Gender Gap Report 2017, India is ranked 108th and it has closed just $67 \%$ of its gender gap, less than many of its international peers, and some of its neighbors like Bangladesh ranked 47 th while China was placed at 100th and with the current rate of progress, it will take India more than 100 years to bridge this gap of gender and inequality as one of the rapidly developing nation it can't wait so long to overcome this issue once for all. And hence it is a huge impetus to reform the educational system of the country to break the shackles of inequality of all kinds, especially gender to pave way towards better India, a prosperous, developed and sustainable nation.

\section{Major Challenges in Gender Equality and Education:}

To achieve gender equality cum equity and very much desired millennium goal of our country since independence i.e. $100 \%$ literacy rate is taking a backseat, which is quite disheartening to see can be attributed to the following reasons. 


\section{a) Inadequate Support System.}

The present support system to curb gender inequality is not working on the desired lines nor guarantees any concrete way out to help the country overcome this dreadful threat. The present system provides very abysmal and dejected look.

\section{b) Weak coordination and monitoring} mechanisms at all levels.

The coordination and monitoring mechanisms are not effective to cater to the needs and aspirations of women folk. Usually a very simple issue is not solved in a time bound manner, which is quite unfortunate and unbecoming, keeping the present advancements in technology in view.

\section{c) Insufficient data and Research.}

Lack of qualitative, real cum authentic data and research also becomes one the major factor to bridge up the gender gap. Surveys usually do not capture all forms of hiccups or challenges faced by women from various places due to diversity in types of violence or issues and culture.

\section{d) Implementation of Government Schemes/Initiatives.}

Various Government schemes and non government initiatives focusing this group causes another blockade in moving towards to the sustainable development due to illness or non implementation. Most of the people are unaware of these schemes or initiatives due to lack of coordination within the government machinery in almost all states of the country.

Way forward towards Sustainable Development:

To achieve gender equality requires the active involvement of men because men still disproportionately control our political, economic, social and cultural institutions which symbolize the patriarchal approach of our society as a whole. According to G7 2018 Summit recommendations, historically, this has been a barrier to women's rights. Conversely, men supporting women's empowerment will mobilize vast resources and institutional and cultural clout. Men's action is also critical because the boys look to men to define the values they associate with manhood. Thus, when men speak out for women's rights or against sexual and gender-based violence, when men challenge their own and others' attitudes and behaviors, this can have a powerful impact - and an increasing number of men are doing exactly that is proving to be a good omen in our society at this point of time and this needs to be continued, replicated and spread all across. We need to recognize the fact that gender equality and women empowerment have a transformative and multiplier effect on sustainable development and are vital agents of economic growth. Following are some suggestive measures that need to be adopted to achieve gender quality in the first instant and sustainable development then after. 


\section{International Journal of Advanced Multidisciplinary Scientific Research (IJAMSR) ISSN:2581-4281}

a) To identify, eliminate all forms of discrimination against women and girls prevalent in our societies.

b) To integrate a gender perspective in priority areas like education for sustainable development.

c) To develop a comprehensive educational set up that is child friendly, gender sensitive and provides free and fair, nonviolent and effective learning atmosphere.

d) To adopt very strict policies, laws and enforceable legislation for the uplift of gender equality and substantial education for sustainable development.

e) To stride forward to ensure women's full, equal and effective involvement in all fields and leadership at all levels and equal rights be given to women with respect to management of economic resources and decision making.

f) To overhaul our present educational curriculum, on account of which we produce an army of unskilled educated people.

g) To encourage policy makers to go for a paradigm shift in educational sector by starting vocational and skilled base programs as early as possible.

h) To mobilize community by integrating various departments to empower women folk to stand on their legs by utilizing their energies in economical and social works. i) To make a subject of Environmental Studies compulsory from upper primary only, so that students could be given awareness regarding the preservation and protection of Mother Earth since childhood to ensure sustainability.

j) To encourage Self Help Groups (SFGs), Non Governmental Organizations (NGOs) arts to reach out to the public to generate awareness regarding sustainable development and its importance.

k) To eradicate extreme poverty and hunger; and universalization of education up to secondary level.

1) To promote sustainable patterns of consumption and production, protection and management of resource base of economic and social development.

\section{Conclusion:}

Sustainable development is related to each and every sector, we belong to, or work for, or we talk about; and aims to address the issues related to them, be it society, economy, politics, geopolitics, science and technology, commerce or environment. It is a long cherished and desired dream of the country since independence to have a sustainable social system, political system or sustainable environmental policy in place so that future generations don't push to wall by destructing and limiting their access to the resources or sources. 
Sustainable development is proving to be a hard task to under developing nations due to lack of education in general and its inaccessibility to the women folk, who is subjected to very illogical, patriarchal and shameful gender inequality. This inequality has crept into our lives because our education system as a whole has not served in this cause. The most policies, programs have always been top to bottom oriented and due to very minimal or no representation of this underprivileged lot at the top has even worsened the situation. Religious orthodoxy, fanaticism and bigotry is also one of the reasons for giving disproportionate shape to our society.

Sustainable development is subservient to education and gender equality. So it becomes an imperative for governments, administration, policy makers at various levels to think of the grave and important issue as soon as possible to uproot the evil of gender inequality from the country at an early to ensure peaceful, harmonious and joyous planet for our future generation without jeopardizing human capabilities. As far as the overall education system is concerned, that needs a huge paradigm shift in setting as well in operation from the bottom to the top i.e. (Primary education to University level).
Attaining sustainable development is not something that can be achieved by having a strong political system, but needs very immense collective efforts and strong socio-political or social-cultural fabric in place.

This newspaper provides a pragmatic mode of thinking around the challenges of gender inequality, and developing it into discrete sets of events and remedial approach thereof. Similarly, measures or steps needed to be taken in the sphere of education to set strong base for a sustainable future.

\section{References:}

1. Bashir, B. (2008). Yemen Paden Me Wechare Gushoe. Bazme Adam Charare sharief Publishers.

2. Brundtland Commission (1987), Retrieved on 25.06.2018 from http://en.wikipedia.org/wiki/Brundtland_Commission

3. Ladd, P. (2013). How to Build Sustainable Development Goals: Intergarting Human Development And Environmental Sustainability In A New Global Agenda.

4. Lazarte,M.(2015, March, 06). Gender equality for a better world. Retrieved from: https://www.iso.org/news/2015/03/Ref1942.html

5. Louden,W.(2013). Essay on gender equality. Retreived from: www.essay.ws/essay-on-genderequality

6. Mohan, D. (2017. September, 29). India's Gender Inequality in Ten Charts. The Wire, Retrieved from: https://thewire.in/economy/ten-charts-genderinequality

7. UNESCO, (1997), Educating for sustainable Future: A transdisciplinary Vision for Concerted Action. Paragraph 89, Retrieved on 26-06-2018, from http://www.unesco.org/education/tlsf/TLSF/theme_a/ mod01/uncom01t05s01.htm

8. Women, U. N. (2014). World Survey On The Role Of Women In Development 2014. Gender Equality And Sustainable Development. United Nations Publication. 